GRZEGORZ LEMAŃCZYK

ALEKSANDER LUKANOWSKI

ANNA BATURO-CIEŚNIEWSKA

Uniwersytet Technologiczno-Przyrodniczy im. J. J. Śniadeckich w Bydgoszczy

Kierownik Tematu: dr hab. inż. Grzegorz Lemańczyk prof. Uniwersytet Technologiczno-Przyrodniczy,

Pracownia Fitopatologii i Mykologii Molekularnej, ul. Kordeckiego 20, 85-225 Bydgoszcz, tel. 52 3749491,

e-mail: grzegorz.lemanczyk@utp.edu.pl

Prace zostały wykonane $w$ ramach badań podstawowych na rzecz postęu biologicznego $w$ produkcji roślinnej na podstawie decyzji Ministra Rolnictwa i Rozwoju Wsi nr HOR.hn.802.10.2018, Zadanie 29.

\title{
Poszukiwanie źródeł odporności owsa (Avena sativa L.) na nowy patogeniczny i mykotoksynotwórczy gatunek - Fusarium langsethiae
}

\section{Searching for oat (Avena sativa $\mathrm{L}$.) resistance to a new pathogenic and mycotoxigenic species - Fusarium langsethiae}

Słowa kluczowe: Fusarium langsethiae, hodowla odpornościowa, owies, postęp hodowlany, realtime PCR, wrażliwość genotypów

\section{ZADANIE NR 29}

Przyczyną fuzariozy występującej na wiechach owsa, jak i kłosach innych zbóż, są różne gatunki Fusarium. W warunkach Polski oraz innych krajów Europy są to głównie F. graminearum, F. culmorum, F. poae i F. avenaceum. Szkodliwość tych grzybów polega nie tylko na zmniejszeniu ilości plonu, ale także na pogorszeniu cech technologicznych ziarna, a zwłaszcza zanieczyszczeniu go mykotoksynami. W ubiegłym dziesięcioleciu w Europie stwierdzono występowanie nowego gatunku tego rodzaju Fusarium langsethiae. Początkowo opisywano go jako prószysta forma gatunku $F$. poae (Torp i Langseth, 1999). Jednak w 2004 r. Torp i Nirenberg prószyste formy F. poae sklasyfikowali jako odrębny gatunek $-F$. langsethiae. W Polsce występowanie tego gatunku po raz pierwszy stwierdzono w 2006 r. (Łukanowski i in., 2008; Lemańczyk 2008). Ze względu na to, że brak wyraźnych objawów porażenia przez $F$. langsethiae na wiechach oraz ziarnie owsa identyfikacja obecności tego grzyba jest możliwa tylko 
w warunkach laboratoryjnych, w tym wykorzystaniem techniki Real-Time PCR. W badaniach dotyczących odporności genotypów na porażenie przez $F$. langsethiae pomocny jest również test liściowy (Imathiu i in., 2009, 2013).

W ramach zadania $\mathrm{nr} 29 \mathrm{w} 2018$ roku wykonywano dwa tematy badawcze:

- analiza odporności owsa na porażenie przez $F$. langsethiae prowadzona w formie testu liściowego,

— analiza odporności owsa na $F$. langsethiae na podstawie jego analizy ilościowej w ziarnie techniką Real-Time PCR.

\section{TEMAT 1. ANALIZA ODPORNOŚCI OWSA NA PORAŻENIE PRZEZ F. LANGSETHIAE PROWADZONA W FORMIE TESTU LIŚCIOWEGO}

Celem tematu było poszukiwanie genotypów owsa odpornych lub wykazujących cechy zmniejszonej podatności na porażenie przez izolaty $F$. langsethiae o zróżnicowanej wirulencji. Badania obejmowały 40 genotypów owsa, w tym 6 gatunków. Oprócz owsa zwyczajnego (forma oplewiona i nieoplewiona), przebadano po dwa genotypy Avena strigosa, Avena fatua, Avena magna, Avena insularis i Avena sterilis. Na przebadane genotypy owsa składało się również 10 odmian, 18 rodów hodowlanych oraz 2 genotypy formy ozimej owsa zwyczajnego. Materiał badawczy pozyskano od firm zajmujących się hodowlą owsa: Danko Hodowla Roślin, Małopolska Hodowla Roślin, Hodowla Roślin Strzelce oraz COBORU SDOO w Chrząstowie. Do sztucznej inokulacji użyto dwa izolaty $F$. langsethiae pozyskane z ziarna owsa (FL 11H4 i FL 298P5) i jeden z pszenicy ozimej (FL 9P1-7). Ocenę wykonano została zgodnie z metodyką opisaną przez Imathiu i in. (2009).

W przeprowadzonym teście liściowym najsilniejszą wirulencją odznaczał się izolat FL 9P1-7 a najsłabszą izolat FL 11H4. Porażeniu przez F. langsethiae uległy wszystkie gatunki owsa. Najdłuższą długość strefy z nekrozą na liściach zanotowano dla formy nieoplewionej $A$. sativa a najkrótszą — dla $A$. sterilis. Długość nekrozy obserwowana dla poszczególnych gatunków była zróżnicowana w zależności od genotypu owsa i izolatu F. langsethiae zastosowanego do testowania wrażliwości.

Spośród 18 przebadanych rodów hodowlanych średnio dla trzech izolatów F. langsethiae najmniej wrażliwym był ród STH 8.25 i POB 3938/14, a najbardziej wrażliwym - DC10067/10/2/4. Zaobserwowano jednak odmienną wrażliwość rodów na poszczególne izolaty patogena. Najmniej wrażliwym na porażenie przez FL $11 \mathrm{H} 4$ był ród DC 10054/8/1/1/1, na FL 298P5 — ród STH 8.30, na FL 9P1-7 — ród STH 8.30. Najbardziej wrażliwymi rodami były odpowiednio DC10061/1/1/2, POB 5710/16 i POB 3938/14.

Spośród 10 odmian owsa najmniej wrażliwą na $F$. langsethiae była odmiana Bingo, a najbardziej wrażliwą - Amant. Najmniej wrażliwą na porażenie przez FL 11H4 była odmiana Bingo i Agent, na izolat FL 298P5 - Bingo, na FL 9P1-7 - Kozak. Najbardziej wrażliwymi odmianami owsa były odpowiednio: Nagus; Armani; Amant. 
TEMAT 2. ANALIZA ODPORNOŚCI OWSA NA F. LANGSETHIAE NA PODSTAWIE JEGO ANALIZY ILOŚCIOWEJ W ZIARNIE TECHNIKĄ REAL-TIME PCR

Celem tematu było poszukiwanie genotypów owsa odpornych lub wykazujących cechy zmniejszonej podatności na porażenie przez $F$. langsethiae na podstawie jego analizy ilościowej w ziarnie techniką Real-Time PCR. Aby zrealizować ten cel przeprowadzono analizę ilościową zasiedlenia ziarna rodów hodowlanych, odmian uprawnych owsa, gatunków owsa przez tego patogena. Badania wykonano dla ziarna 40 prób genotypów owsa pochodzących $\mathrm{z}$ doświadczeń prowadzonych $\mathrm{w}$ warunkach naturalnych, oraz 15 genotypów z doświadczenia ze sztuczną inokulacją $F$. langsethiae. Analizę-Real Time PCR przeprowadzono z użyciem specyficznych gatunkowo starterów i barwnika SYBR Green I na termocyklerze LIGHTCycler 480 II firmy Roche.

Wykorzystując technikę Real-Time PCR stwierdzono zróżnicowanie wrażliwości genotypów owsa pozyskanych od firm zajmujących się hodowlą. Najwyższe stężenie DNA F. langsethiae odnotowano w próbach pochodzących ze Strzelec, znacznie mniejsze $\mathrm{w}$ próbach $\mathrm{z}$ Kopaszewa i Polanowic. Średnio największe stężenie DNA F. langsethiae stwierdzono w ziarnie rodu hodowlanego POB 3938/14, najmniej w ziarnie rodu DC 18-4.

W ziarnie odmian owsa pozyskanych z doświadczeń prowadzonych przez COBORU najwięcej grzyba stwierdzono w ziarnie pochodzącym z ZDOO Dukla, znacznie mniej z ZDOO Żabnica i SDOO Wrócikowo. Średnio z trzech miejscowości największe stężenie DNA F. langsethiae odnotowano w ziarnie odmiany Romulus a najmniejsze w ziarnie odmiany Monsun.

W ziarnie owsa pochodzącego $\mathrm{z}$ doświadczenia, w którym prowadzono sztuczną inokulację wiech grzybem $F$. langsethiae średnie stężenie tego patogena wynosiło 12872,94 pg DNA / kg ziarna owsa, natomiast w kombinacjach kontrolnych bez sztucznej inokulacji - 1,44 pg DNA / kg. Najwyższe stężenie F. langsethiae stwierdzono w ziarnie odmiany Krezus. Grzyba tego nie stwierdzono w ziarnie rodów hodowlanych DC10067/10/2/4, POB 5547/16, STH 11215 i STH 11315. W kombinacji kontrolnej obecność patogena odnotowano tylko w ziarnie rodów hodowlanych DC 10054/8/1/1/1, POB 3913/14, owsie głuchym i owsie szorstkim.

W wyniku przeprowadzonej izolacji grzybów na pożywce PDA, z ziarna owsa o różnym genotypie, izolaty $F$. langsethiae stanowiły $0,06 \%$. W próbach tych stwierdzono również różne gatunki grzybów rodzaju Fusarium, spośród których dominował F.poae. Rzadziej izolowano F.avenaceum, F.graminearum, F. sporotrichoides, F. tricinctum, F. culmorum, F. equiseti i F. crookwellense. Ziarno owsa najczęściej było zasiedlone przez gatunki saprotroficzne, przede wszystkim Alternaria alternata, rzadziej Epicoccum nigrum i Gonatobotrys simplex. 


\section{WNIOSKI}

1. Izolaty Fusarium langsethiae cechowały się zróżnicowaną wirulencją wobec badanych liści owsa. Najsilniejszą wirulencją odznaczał się izolat z pszenicy - FL 9P1-7, a najsłabszą izolat FL 11H4 (z owsa).

2. Wszystkie przebadane gatunki owsa były porażane przez F. langsethiae. Większą długość nekroz charakterystycznych dla porażenia $F$. langsethiae stwierdzono na liściach owsa zwyczajnego nieoplewionego, a najmniejszą na liściach Avena sterilis.

3. W teście liściowym odnotowano zróżnicowanie w podatności analizowanych rodów hodowlanych owsa na $F$. langsethiae. Najmniejszą wrażliwością odznaczały się rody hodowlane STH 8.25 i POB 3938/14, a najbardziej wrażliwym był ród DC10067/10/2/4.

4. Spośród odmian najmniej wrażliwą na $F$. langsethiae okazała się odmiana Bingo, a najbardziej - Amant.

5. Duża czułość analizy Real-Time PCR na obecność $F$. langsethiae w ziarnie owsa okazała się przydatna $\mathrm{w}$ określaniu podatności owsa na porażenie przez tego patogena.

6. Obecności DNA grzyba nie stwierdzono w ziarnie rodów hodowlanych: DC10067/10/2/4, POB 5547/16, STH 11315 i STH 11215. Z przebadanych odmian najmniej grzyba odnotowano w ziarnie odmiany Monsun.

7. Zarówno w teście liściowym jaki i analizie Real-Time PCR nie stwierdzono istnienia genotypów owsa całkowicie odpornych na porażenie przez $F$. langsethiae.

8. Genotypy owsa, dla których w zebranym ziarnie nie stwierdzono obecności F. langsethiae mogą stanowić podstawę do uzyskania odmian o istotnie ulepszonej odporności.

\section{LITERATURA}

Imathiu S. M., Edwards S. G., Ray R. V., Back M .A. 2013. Fusarium langsethiae - a HT-2 and T-2 Toxins Producer that Needs More Attention. J. Phytopathol. 161: $1-10$.

Imathiu S. M., Ray R. V., Back M., Hare M. C., Edwards S. G. 2009. Fusarium langsethiae pathogenicity and aggressiveness towards oats and wheat in wounded and unwounded in vitro detached leaf assays. Eur. J. Plant Pathol. 124: 117 - 126.

Lemańczyk G. 2008. Zasiedlenie ziarna pszenicy ozimej przez grzyby rodzaju Fusarium w zależności od zdrowotności podstawy źdźbła, Zesz. Probl. Post. Nauk Roln. 529: 65 - 71.

Łukanowski A., Lenc L., Sadowski C. 2008. First report on the occurrence of Fusarium langsethiae isolated from wheat kernels in Poland. Plant Dis. 92 (3): 488.

Torp M., Langseth W. 1999. Production of T-2 toxin by Fusarium resembling Fusarium poae. Mycopathologia 147: 89 - 96.

Torp M., Nirenberg H. I. 2004. Fusarium langsethiae sp. nov. on cereals in Europe. Int. J. Food Microbiol. 95: $247-256$. 